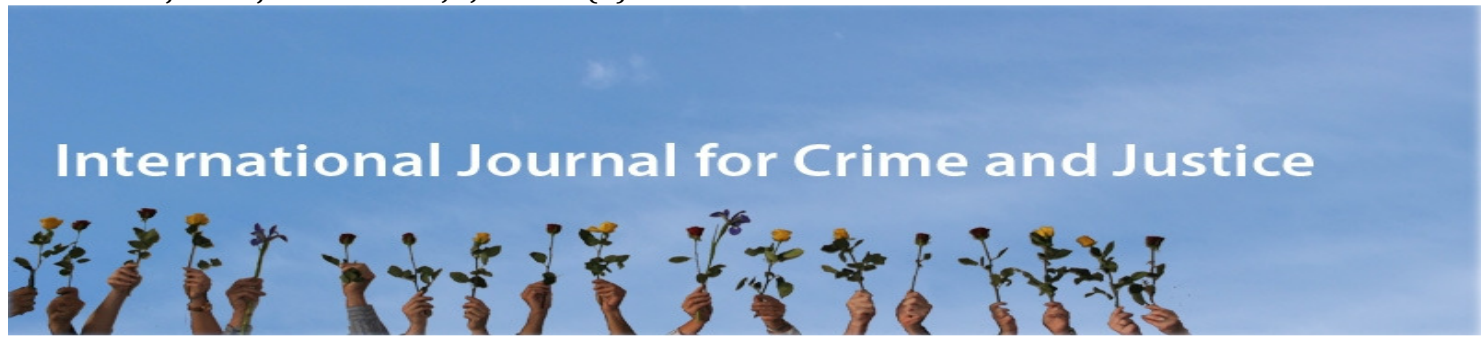

\title{
Fighting Terror with Law? Some Other Genealogies of Pre-emption
}

Mark Finnane ${ }^{1}$

Griffith University, Brisbane

Susan Donkin²

Griffith University, Brisbane

\begin{abstract}
Within criminology and criminal law the reception of post-9/11 counter-terrorist law has generally been critical, if not hostile. The undeniable proliferation of preventive statutes has been regarded as incompatible with conventional liberal norms and as dangerously innovative in its embrace of new strategies of control. But is such law innovative, and does it threaten to leach into other areas of criminal law, as some have feared? Exploring three governmental innovations - mental health law, habitual criminal controls, and civilian internment in war-time - that developed as expressions of the liberal state's desire to ensure the safety of its citizens in times of peace and war, we argue that a more historically grounded understanding of the governmental and geopolitical contexts of security provides a surer foundation on which to construct the frameworks of interpretation of contemporary counter-terrorism law.
\end{abstract}

\section{Keywords}

Pre-emption, counter-terrorism, history, security, policing.

\section{Introduction}

Within criminology and criminal law, the reception of post-9/11 counter-terrorist law has generally been hostile. The proliferation of preventive and punitive statutes has been regarded as incompatible with conventional liberal norms in criminal law and as dangerously innovative in its embrace of new strategies and new categories of control. In many such critiques, neologisms and semantic shifts abound - pre-emption, pre-crime, securitisation - in an effort to capture what appears to be a whole new world of actions and meanings. In the perspectives of some of those writing within the framework of criminal law and criminology, there has been a particular desire to contest the metaphor of balance - to undermine the claim that there is a kind of zero-sum game in which security and liberty must always be balanced - with the alarming spectre of a decline in hard-won liberties in the face of rising (or constructed) terrorist threats (Bronitt and Stellios 2006; Lynch 2007; Zedner 2005). 
In spite of some attempts within criminology to moderate the terms of this debate (for example, Loader and Walker 2007), we see a continuing tendency from within the field to interpret the deployment of counter-terrorism law as one that has, above all, to be seen in the light of its derogation from human rights and due process principles embedded in the modern development of criminal law (Ashworth 2009; Bronitt 2008; Gani 2008; International Commission of Jurists 2009; Michaelsen 2005). The introduction of terrorism control orders ${ }^{3}$ in the United Kingdom and Australia is a frequently cited example. The statutory constructions of the last decade have spawned, in turn, a literature focussed on pre-emption and pre-crime, concepts that have been constructed to capture what is seen as a core characteristic of the contemporary securitised state (De Goede 2008; McCulloch and Pickering 2009; Zedner 2007, 2009). But how innovative are such strategies in the government of security in the modern state? In this article, we propose that scholarship in counter-terrorist law will benefit from considering some other trajectories along which the modern liberal state has developed as a mode of governing populations in peace and war.

While there are a number of notable works attending to the history of political violence, counter-terrorism and state response (Bonner 2007; Bowden and Davis 2008; Donohue 2001; Lustgarten and Leigh 1994; Richardson 2006; Simpson 1992; Townshend 1986), their impact in the criminology and criminal law literature arguably has been muted. The risk of historically shallow ethical evaluations of contemporary counter-terrorist strategy is that of the boy crying wolf once too often: we lose our capacity to appreciate what is happening around us through the continuing invocation of threats. Ironically such a stance ends up being little more than an intellectual moral panic, an inversion of the very conditions that contemporary social science has so often discerned in the moral and political worlds that are its object of attention.

In proposing a more historically self-conscious evaluation of counter-terrorist law as an arm of the contemporary state, this article asks us to recall the continuities in the history of liberal government's engagement with threats and dangers. Ashworth (2009) has emphasised the necessity of 'security' as a starting point for exploring the criteria by which its advancement might be compatible with liberal theory more generally. Acknowledging the breadth of the field of social action in security strategy, he notes that criminal law is just one of a variety of state strategies that requires evaluation against criteria derived from human rights conventions, liberal theory and so on. We propose that the evaluation of security strategies needs to reach beyond such normative criteria to the historically shifting political conditions of modern states if their rationale and effects are to be understood adequately. In a compelling recent critique of the application of the norm/exception distinction to the study of emergency powers, Nomi Claire Lazar has highlighted the importance of recognising the 'strong continuities between emergency and everyday relationships between order and justice' (Lazar 2009: 50). Emergency, in her words, 'has rarely been lawless' and criminal law is just one example of rights derogations in everyday life (Lazar 2009: 50-1). Against all the metaphysical hyperbole of 'bare life' (Agamben 1998; cf Saunders 2010) that threatens to dominate evaluation of contemporary social and political order, a rhetoric which privileges philosophical positions at the expense of practical, empirical knowledge, Lazar invites us to reconsider the continuities in the life of liberal states and modern government. In this context, what we address in this paper is the reality of a variety of strategies of security that have been long pursued by the modern liberal state outside the purview of the criminal law. As Lazar notes, order and justice are not separate and opposed but inter-twined: 'without rights, liberal democratic order would be contentless, and without order to describe rules and their enforcement, rights would be potential only' (Lazar 2009: 98). Criminal law itself is the archetypal example of rights derogations in everyday life, in the 'enforcement and preservation of order'. To the extent that this is true, then Lazar suggests that emergency powers themselves 'are an extension of everyday practice and everyday values' (Lazar 2009: 99-100). 
In the context we address here, outside the formal institutions and practices of criminal law, we observe that liberal states since the late eighteenth century have limited rights forcefully, but not without law, and not beyond accountability. The ways in which they have done so however also highlight how far political contests around rights derogations are themselves the groundwork for modifying the governance of rights and rights derogations. Hence, in what follows below, we seek to broaden the understanding of the range of measures that have been in play for a very long time at different points of development of modern liberal government. We suggest that contemporary assessments of counter-terrorist law are better judged against the entirety of governmental approaches to security, rather than limited to the narrower, though unquestionably important, field of criminal law. In this respect, the article is less concerned with pursuing the merits of the debate over how to proceed as if terror was crime, or terrorist actions the actions of criminals, than to understand how it may be possible that actions (and persons) that lie outside criminal law's conventional concern with harmful acts have become subject to the liberal state's control.

Our analysis looks at three important examples of state intervention against individuals on grounds of security. Importantly their deployment ranges across conditions of both peace and war. We will argue that modern mental health legislation has its origins in the liberal state's desire to protect citizens against dangerous acts directed against themselves and others. This is a legacy that remains a cogent element in contemporary mental health legislation. Arguably its very rationale has become so deeply embedded in our presumptions that its relevance to our concerns with understanding the contours of the security state is underestimated. ${ }^{4}$ Second, we will consider the legal-administrative framework for the use of internment as a security strategy that has been employed in conditions of war and even in conditions below the threshold of inter-state war. Third, we consider the rationale and use of habitual criminals legislation, a nineteenth century strategy serving crime prevention and security-maintenance purposes, also informing the more widespread deployment in modern penality of alternative sentencing and post-release surveillance and control. We will see that all of these strategies, as much as they sit outside the conventions and protections of criminal law, were nevertheless made possible by and hedged around by law, for good or ill as the case may be, and transformed over time by a politics that shaped new modes of their administration. Indeed such strategies of social control in the interests of security exemplify those very derogations from rights that so consistently point to what Lazar has characterised as the continuum (rather than opposition) between norm and emergency. In conclusion, we comment on the implications of this analysis for the way in which we estimate the contemporary significance of counter-terrorist law.

\section{Dangerous lunatics}

In what was known in the nineteenth century as 'lunacy law', there were two substantive concerns: one to do with the lunatic's property; the other with the lunatic's behaviour and state of mind. The second concerns us here and was related to the longer term development of modern mental health law. Though it applied to few people, the refinement and deployment of the insanity defence in criminal trials was the origin of institutional provision for a major exercise in preventive detention. At key moments in the Georgian and Victorian eras, this defence was agitated around the fate of assassins or potential assassins of sovereigns, heads of state and leading public officials. It was through such moments that insanity became a matter of public policy as well as a challenge to the favoured reasoning of criminal law (Eigen 1995; Moran 1985a; Smith 1981; Walker 1968).

The difficulty faced by the criminal law in dealing with the threat posed by inexplicable and unpredictable attacks on prominent and ordinary persons was met by a nineteenth century invention of statute and administration: the category of the dangerous lunatic. In a development that drew limited attention in the ranks of criminal lawyers, persons considered dangerous lunatics could be confined indefinitely in a prison or lunatic asylum in the interests of 
prevention of crime. This was the objective specified in the first nineteenth century lunacy statute, one that formalised long-standing powers of preventive detention (Dershowitz 1974a). The Criminal Lunatics Act was enacted in 1800 after James Hadfield made an attempt on the life of George III. There had been previous such attempts on the life of the sovereign, and some success in mounting a defence of insanity. From Hadfield's attempt, however, and his subsequent acquittal by a jury on grounds of insanity, flowed the statutory invention of the dangerous lunatic. 'An Act for the safe Custody of insane person charged with Offences' was passed shortly after, ensuring that Hadfield would be detained at the King's pleasure. Persons unfit to plead might also be confined, and the legislation further attempted to circumvent habeas corpus actions for the release of 'persons about to be discharged for want of prosecution who appeared to be insane' (Walker 1968: 80).

The Act went beyond this, however, and in ways that would prove influential in their use against a wide range of people in many jurisdictions The 1800 statute linked the control of the insane with the prevention of crime when it 'made it possible for the justices to confine certain insane persons without the possibility of private bail, so that only two justices, or a higher authority, could release them'. This power, which Walker (1968: 80) commented 'seems a fairly sweeping one', was notionally limited to 'any person discovered and apprehended under circumstances that denote a derangement of mind and a purpose of committing an indictable offence'. The rationale for Section 3 of the Act that made this action possible was spelt out in the preamble, namely 'for the better Prevention of Crimes being committed by Persons insane' (Walker 1968: 78-80). Over the longer term, the power embraced by this statute became the mechanism by which certification or compulsory confinement became a routine matter in the management of mental illness through the enormous nineteenth-century growth of the public lunatic asylum (Finnane 1981: 89-90). The discursive links to crime prevention never quite vacated the field of what today we call mental health law.

Was the 1800 Act a historical accident, no better than a hyper-reaction to the latest attack on the King? We suggest not. 25 years ago, Richard Moran published a detailed study of the context of Hadfield's attack, the subsequent trial and the consequent legislation, which established conclusively that the 1800 legislation was no measure of humanitarian intent but designed specifically with preventive detention in mind. The attack on the sovereign was critical to this outcome. Not only was there evidence that Hadfield's attack was linked to the generally threatening millenarianism of these revolutionary years but the choice of charge also entitled the defendant to a range of legal privileges. Proceeding via a charge of high treason (no mere felony), the government found that Hadfield had at his disposal unusual entitlements to legal defence while the prosecution was burdened with the requirement that conviction depended on the testimony of at least two witnesses rather than one (as for an ordinary felony). An important result of the experience with Hadfield was the government's determination to ensure that 'future Hadfields would not be granted the special rights afforded defendants in political trials' (Moran 1985b: 511). In fact, the 1800 Act 'for the safe custody of persons insane' had its legislative origins in a bill that combined this purpose with the classificatory one of making the attempted murder of the King into an ordinary felony. As Moran argues, the subsequent splitting of these two purposes into separate bills 'perhaps explains why legal historians and other scholars have overlooked the direct connection between the loss of legal rights of Englishmen in political trials and the origin of the plea of insanity as a special verdict' (Moran 1985b: 511).

Against this background we can see how significant a development we are tracing here. Lunacy incarceration was a parallel system of detention running along-side the criminal law and its institutions (Dershowitz 1974a). By applying a specific set of constraints to those found either insane during a criminal process or insane before and outside of a criminal process, the 1800 Act also fostered the development of the asylum as a carceral accommodation separate from the prison. The uses of the law and the deployment of institutional resources to accommodate the 
dangerous lunatic would vary across jurisdictions. The 1800 English Act imagined the dangerous lunatic in prison but the invention of the lunatic asylum was the condition of an amendment of the law in 1838 which prohibited their accommodation in prison. Across the Irish Sea, the homicide in Dublin of a 'respectable gentleman' in 1837 was a prelude to the introduction in Ireland of the Dangerous Lunatics Act, a statute which allowed the incarceration in prison of a person found insane by the process of certification in a magistrate's court. For reasons which have been explored elsewhere, even after the 1867 amendment of this Irish statute, the certification of a person as a dangerous lunatic became and remained the dominant mode of admission to Irish mental hospitals (Finnane 1996; Prior 2003).

In other places which inherited the dangerous lunatic laws, we can find similar evidence of a high rate of use of this magisterial order for confinement of those suspected insane and dangerous. In Australia, the 1843 Lunacy Act in New South Wales derived its preamble and provisions from the Acts of the imperial parliament, again linking the certification of insanity to the evidence of a dangerous purpose (Garton 1987). When the Victorian colonial parliament revised and consolidated its lunacy legislation in 1867 it retained all those provisions making it possible to confine a person showing both a 'derangement of mind' and a purpose of committing suicide or an indictable crime (Coleborne 2003). The frequency with which the Imperial Sovereign herself was subjected to attack by a great variety of individuals wielding anything from sticks to pistols loaded with tobacco or more fatal materials, kept alive in British consciousness at home and abroad the necessity of finding ways of restraining those thought mad and dangerous (Smith 1981; Walker 1968). In a variety of American jurisdictions the legal innovation of civil confinement of persons dangerous to themselves or others shaped the mass incarceration of the mentally ill (Dershowitz 1974b; Fox 1978; McCandless 1996).

Over time, the occasional testing of this power resulted in a jurisprudence which generally ignored the coercive element of the law in favour of what was held to be its 'paternalist' purpose. Reviewing this litigation in a treatise on the law of habeas corpus, RJ Sharpe ruminated over the source of the power to refuse discharge of a person illegally committed 'simply because the court suspects he or she may be dangerous' (Sharpe 1989: 158). He concluded that in such cases, it seems to be assumed that 'there is an inherent sort of parens patriae jurisdiction which is exercisable to protect the interest of the public and of the patient'. It was a kind of reasoning he could not find in criminal cases 'where, very often, there is little doubt about the prisoner being dangerous' (Sharpe 1989: 158). Post-war thinking changed this presumption and the revolution in psychiatric care associated with the emergence of psychotropic drugs probably helped make it possible to detach 'dangerous' from 'lunatic' in ways that had not seemed possible for more than a century: after one habeas corpus action in the mid-1950s more than 3,000 people in England were released from their asylum custody. The statutory protections which have accompanied deinstitutionalisation and an emergent politics of human rights of the mentally ill cannot disguise this longer history of the use of compulsory confinement in modern liberal states of a significant portion of the population, a confinement that is preventive detention and that has its origin as an exercise in crime prevention.

\section{Enemies of the state}

Conditions of war test liberal states grievously. What happens to the liberty of those within states during such times helps us understand the limits of what a liberal state might be, and what demands the pursuit of security makes on liberty. In this section we look briefly at how life is governed in conditions of emergency attendant on declarations of war - in particular to highlight the ways in which criminal law takes a back seat while emergency law (executive command flowing from constitutional and statutory powers, military law, administrative regulation) nevertheless saturates life in such times. Importantly, while historical experience of twentieth century war has demonstrated just how great restrictions on liberty during war-time 
may be, it is also valuable to recall how quickly such emergency law can retreat after the cessation of war.

A good test of how liberal states respond in times of war is the modern history of internment. This was a preferred mode of response to the management of those who came to be identified as enemies or enemy aliens in both the world wars of the twentieth century. But it has also been an instrument of state offensive against security threats in a variety of other kinds of conflict, including in a terrorism-related context in Northern Ireland as late as the1970s (Bonner 2007; Townshend 1986).

The widespread use of internment on both sides in the Great War led to a large degree of reflection in the war's aftermath and, in the lead-up to World War II, internment of civilians was expected to be used in a much narrower frame (Bevege 1993; Bonner 2007; Fischer 1989; Simpson 1992). One issue was the enormous cost of comprehensive internment. A second was its clear inequities and even counter-productive effects when used against people whose birth origin rather than current sympathies made them suspected enemies of the state. The Great War was a crucible for the advanced police state of the later part of the twentieth century: the seductiveness of the apparatuses of intelligence, surveillance and control which the war made possible meant that there were those in the war's aftermath who would have liked to see the extension of war-time controls into peace-time conditions (Finnane 2009).

The institutional and legal frameworks of internment in Britain have been comprehensively examined elsewhere, in particular to note the limited availability and impact of judicial review, but also the executive and administrative modification of internment regimes over time in the conditions of war-time emergency (see, for example, Bonner 2007; Simpson 1992). Those features were evident in other jurisdictions of liberal government. In Australia, the declaration of war in 1939 was accompanied almost immediately by the enactment of the National Security Act, as had long been planned. This enabled a very wide range of executive action through regulation. Regulation 19 provided for the registration of aliens, an exercise that was carried out by police in their capacity as Alien Registration Officers, a role originating in the previous war. Regulation 26 provided for internment. Aliens were restricted in their freedoms in a variety of respects, especially in mobility and employment; those interned were most adversely affected, having been detained in camps located around the country and distant from their families. But within these war-time conditions under the demanding and extensive powers encompassed in the National Security Act, a multitude of measures developed to alleviate the impositions and hardships that resulted. While internees did not have appeal 'rights', they were able to mount objections to their treatment, objections which were commonly referenced in administrative correspondence under the rubric of 'appeal'. ${ }^{5}$ The Australian processes followed closely those adopted in Britain, with administrative review committees of legally qualified members taking the lead role in processing release of those interned. Advisory Committees chaired by a judge or retired judge were appointed soon after the commencement of war to hear the objections of British subjects (that is, in the Australian context, non-alien) who had been interned. In January 1941, the model was extended to cover interned aliens. Aliens Tribunals were charged with recommending the release of internees who had satisfied the tribunal that the person was not a danger to public safety or defence of the Commonwealth. Even historians critical of internment have noted the independence of the Tribunals, in the face of the hostile military and security assessments on individual cases.

In the conditions of war the preventive function of internment operated from both ends: to protect the public from its enemies, and to protect the internee from the enmity of the public. In Australia as in Britain, the extension of internment to whole ethnic communities was as much the result of public as military pressure. This was implied in an additional criterion for release, with the requirement that the Tribunal be satisfied that 'release would not be likely to occasion serious unrest in any Australian community' (Neumann 2006: 17). Neither was this an idle 
requirement since a strong factor driving internment policy was the often rabid and even dangerous public sentiment about enemies in their midst. In the United States (US), such hostility was a reason for many Japanese internees seeking continued residence in internment camps, so as to avoid returning to hostile neighbourhoods on the west coast (Ngai 2004).

Beyond the conditions of internment, there was the question of the treatment of those aliens still resident in the community. The composition of immigrant communities in numerous countries included both friends and enemies. In consequence, the task was one, in liberal states as much as totalitarian ones, of distinguishing between the two, a process that resulted in the construction of the oxymoron 'friendly enemy aliens'. The similarities of the tasks and approaches in both kinds of states are evident in a 1942 study of internment policies that were known at that time in the UK, France, Germany and Italy (Koessler 1942). In Australia, the initial control of aliens by military order, with the assistance of police at local level, devolved after April 1942 to the new Commonwealth Security Service. Six months after the Japanese bombing of Darwin in February 1942, a new security directive loosened the earlier highly restrictive controls over the movements of aliens who had not been interned. So-called 'restriction orders' (akin to contemporary control orders in anti-terrorism law) were in place for more than 3500 aliens at the height of the war. The majority of these applied to people who had previously been interned. The weight of internment fell unevenly on the potential subject population (largely alien males) with high rates of internment especially evident in Queensland, the jurisdiction closest to a theatre of war. Almost all Japanese males were interned, but only a third of Italians (then the highest proportion of non-Anglo ethnic born in Australia) and Germans. Internment's rationale was, in the words of Attorney-General HV Evatt in 1942, 'preventive' rather than 'punitive', and the range of administrative review bodies, permanent and ad hoc, put in place during the war demonstrate this. They included the Advisory Committees dealing with British subject suspects who were interned owing to membership or activities in relation to subversive organisations; the Alien Tribunals to hear appeals by enemy aliens; the Aliens Classificatory and Advisory Committee; and a number of reviews chaired by judges into the status of particular categories of internees or aliens (Finnane 2007; Lamidey 1974; Neumann 2006).

As this brief summary of its administration indicates, war-time internment in Australia developed within a legal framework that was shaped by political decision and intended to modify the impact of executive discretion. Emergency conditions and occasionally war hysteria drove decisions to intern particular individuals, as they did in Britain and the US. However, resource demands as well as governmental interests, including the management of the controversy that accompanied many internment orders, drove government quickly into review processes that resulted in large numbers of internees being released long before war's end.

As a security strategy, internment has its rationale in the twin constraints of speed of action and uncertainty of knowledge. Its damaging consequences for individuals and families are never to be underestimated, nor is its countervailing potential for aggravating the conflict it seeks to address. Arguably the consequences for individuals fall short of, or are no worse than, those flowing historically from compulsory confinement on a lunacy or mental health order: that is, the hardship of prolonged detention with no known prospect of release. The widespread use of internment by both liberal and authoritarian states in times of peace and war, in domestic and in colonial conditions, points to the long history of governmental strategies that operate by something other than the kind of due process standards applying in criminal law. At the same time, the history of these preventive procedures shows the adaptation of liberal states to the political and administrative contradictions opened up by such innovative measures, with a consequent evolution of administrative procedures intended in part to moderate the harsh impact of emergency laws. 


\section{Habitual and dangerous criminals}

The discussion of mental health law and of internment has highlighted the use by liberal states of strategies of containment that targeted individuals on the basis of future risk of dangerous or subversive actions. In considering the development of policy on the constructs of 'habitual' or 'dangerous' criminals, we come closer to the evolution of modern criminal justice policy and its associated penality. We also see the emergence of strategies of control that prefigure those deployed in counter-terrorism more recently. As the previous examples have demonstrated, dangerousness was long associated with individuals or groups of people who were seen to threaten domestic order as well as the very existence of the state. Developments in the nineteenth century led to increased and more rigorous recording of the lives of offenders in prison and police custody, highlighting the repeat offending of certain individuals. Rather than endangering society as a whole, habitual offenders were perceived as a threat to individuals and their property. In the notorious 'garrotting' panic of 1862-3, one reaction was to re-introduce flogging, as enacted in a statute bearing the instructive title 'Security from Violence Act' (Radzinowicz and Hood 1990: 692). Nevertheless, a powerful stream of opinion associated with the Irish prisons administrator Walter Crofton sought protection from these dangerous individuals by way of prevention through longer detention and supervision after release. The Victorian era innovation of tracking habitual criminals through their registration on release from prison was a harbinger of later developments, even if limited in its effectiveness at the time (Williams 2011).

At the turn of the twentieth century, different jurisdictions responded to the threat of habitual criminals by introducing indeterminate sentencing and preventive detention, as in the Habitual Criminals Act (NSW) 1905 or the Prevention of Crime (UK) Act 1908. Depending on jurisdiction, before 1949, in the so-called dual track system, preventive detention could be imposed either in lieu of or in addition to a penal sentence (Morris 1951). In Britain, these policies were justified as necessary to manage the risk posed by persistent offenders in order to protect its citizens (Pratt 1997). In practice, however, preventive detention was imposed relatively infrequently, partly due to the belief that it was too excessive a sentence (Forrester 2002), and the judiciary's unease with using detention as a form of crime prevention. Despite limited practical application of the 1908 legislation, the principle of preventive detention was extended in the Criminal Justice Act (UK) 1948. This post-war reform replaced the construct of the habitual criminal with that of the persistent offender whose future behaviour should be the object of correction through training while in detention. Section 21(2) of the statute provided that such offenders could be detained in custody for a lengthy period 'if the court is satisfied that it is expedient for the protection of the public' (Pratt 1997: 56).

The utility of such preventive detention was diminished, nevertheless, by the 1960s, with research showing that the majority of preventive detainees were convicted of property crimes, many of which were petty (Daunton-Fear 1967; Forrester 2002; Pratt 1997). Only about 10 percent of detainees had committed serious violent or sexual offences. In a fundamental shift, the habitual offender began to be characterised as psychologically immature and not, as previously thought, exhibiting anti-social or dangerous tendencies. A treatment component was introduced, focusing on supporting reintegration into society with educational and vocational training. We note that this development is somewhat similar to the paradigm shift referred to earlier in mental health: that is, the reinvention of the mentally ill person from being the risk to being at risk, thus requiring the state's protection rather than vice versa. However, this shift was relatively short lived and preventive detention was replaced by the innovation of extended sentences. In essence, this empowered the courts to extend a sentence beyond the statutory maximum for the purpose of protecting the public from offenders who were likely to re-offend.

The moral panics of the 1860s thus spawned a long chain of responses from the liberal state in dealing with the challenge of habitual offenders. The use of preventive detention, notionally an 
alternative to a prison sentence, did not stand alone in governmental pursuit of public security: as we have seen, lunacy incarceration or civilian internment in war-time operated with such preventive logic. Such a rationale also informed an off-shoot development of habitual criminal detention that was associated with what Pratt described as the sexualisation of risk (Pratt 1997: 120). While offences 'of a sexual nature' had, in many jurisdictions, been among those commonly linked to the construct of the habitual criminal whose danger to society justified preventive detention (Morris 1951), the decades after World War I witnessed a heightened anxiety about sexual offenders.

In the 1920s, some US states required habitual criminals to undergo psychiatric evaluation. Those not conforming to either the insane or mentally disturbed categories were assigned their own label: psychopaths. An apparently new class of offender conforming neither to the mental degenerate nor the habitual offender had been created. This new offender, difficult to control, began to be associated with crimes of a sexual nature during the depression in the $1930 \mathrm{~s}$, as economic hardship affected and challenged the traditional male status. Two waves of panic and fear swept the US in the late 1930s and early 1950s following a string of high profile sexual homicides of children. Sensationalised media coverage of the events along with pressure from concerned parents and law enforcement agencies pressured state governments into passing sexual psychopath laws which introduced indefinite detention for sexually violent criminals. The pressure further increased after J Edgar Hoover's declaration of war on the 'sex criminal' in 1937. Despite a reduction in sexual offences post-war, the second wave of panic resulted in almost half the US states featuring new psychopath laws in their repertoire, although in most states (as in Britain) these were rarely used (Freedman 1987; Sutherland 1950; Wormith and Ruhl 1986). As Freedman noted, once again, fear had proved a powerful ally in 'mobilizing political support against nonconforming individuals' (Freedman 1987: 106).

In a move away from outlawing specific acts, sexual psychopath laws targeted particular personalities deemed capable of sexual violence. Two divergent approaches developed: one seeking greater police powers; the other focused on psychiatric intervention. The latter approach saw psychiatrists playing an increasingly influential part in both the legal arena and government security strategies (Cole 2000). In support of the new legislation, medical expertise was presented as evidence of the effectiveness of treatment methods. The rationale of the legislation was to protect society from these individuals by detaining them indefinitely in institutions. Special, purpose-built establishments were commissioned and early screening programs were introduced in an effort to identify and thus pre-empt offending.

Sutherland (1950) observed that detention of sexual psychopaths was not punitive: even where it followed conviction, ${ }^{6}$ such detention aimed to protect society. He saw this as a reflection of a more general trend in criminal justice and society as a whole, moving away from punishment towards a more treatment-focused approach, one which was also occurring across the Atlantic in Britain. However, Sutherland warned that despite this apparent shift toward treatment, it was still being carried out within a punitive framework, a theme also informing Morris' evaluation in 1951.

The dangerousness of this group of offenders was amplified by their association with crimes of sexual violence: the moral enormity of the threat was signalled by an emerging discourse of 'evil' (Simon 1998). By the 1990s, the management of such offenders in the interests of public safety re-emerged as a challenge for governments and policy makers, and prevention was given a new life (Brown and Pratt 2000). For instance, New Zealand re-introduced preventive detention for sexual and violent offenders, and extended sentences were available for persistent violent sexual offenders in Britain. The aim of the more recent Queensland Dangerous Prisoners (Sexual Offenders) Act 2003, which introduced indefinite preventive detention for child sex offenders, is to protect the community from further offences by such offenders. The underlying rationale of the measure was not punishment but crime prevention and public protection. ${ }^{7}$ The 
High Court of Australia (with Kirby J dissenting strongly) concluded that, where incarceration was ordered for non-punitive reasons, it was not technically considered punishment and should be interpreted as protective (Fardon v Attorney General (QId) (2004) 223 CLR 575 at 612). Our review of the history of such detention suggests that preventive and protective rationales have for a very long time informed the practices of liberal states in pursuit of security, domestic and national, creating systems of incarceration that run parallel to other criminal justice practices.

\section{Conclusion}

Historical examination of liberal states' responses to control dangerous groups and individuals illustrates multiple shifts and several instances of history repeating itself (Ashworth 2010: 195 ff). However, the plethora of contemporary measures such as anti-social behaviour orders - civil orders imposing restrictions on an individual, usually requested by police or the local authority, in the UK; or control orders in Australia - for both terrorist suspects and members of outlaw motorcycle gangs, recall a variety of approaches that have dealt with certain groups of individuals outside the criminal law framework. The overarching rationale of public protection shapes the always controversial preventive and pre-emptive measures employed in times of both peace and war. Even in times of peace, the war rhetoric is often employed by governments in an effort to amplify the severity of a situation they deem to be an emergency, thus justifying derogations from the more limited rights protections associated with criminal law. Historically, the judiciary has been reluctant to impose detention in anticipation of future misconduct but has also been reluctant to interfere with such detention when mandated by statute (Dyzenhaus 2006; Simpson 1992). Its reluctance (though by no means a unanimous position) highlights the plethora of preventive strategies that sit outside the criminal law yet lie clearly within the historical reach of liberal government.

In this article, we have suggested that in focussing on criminal law and criminological concerns as the standards against which contemporary counter-terrorism law should be judged, we risk failing to recognise the degree to which liberal states have developed and practiced a range of strategies targeting anticipated dangers outside the formal processes of criminal law. Others have drawn attention to the weakness of human rights conventions (such as the European Convention on Human Rights) in the face of contemporary prevention strategies that lie beyond or outside of criminalisation (Ashworth 2009). Such criticism is, of course, warranted, given the framework within which criminal law and criminology has come to judge criminal justice system formal (for example, statutory) and procedural (policing as well as prosecution) systems. Yet the necessarily limited focus of criminal law and criminology on criminal justice per se has also become a straitjacket when it comes to assessing the generation and function of contemporary counter-terrorist law.

By extending our vision beyond criminal justice to capture the wide range of security-oriented strategies of liberal government we can appreciate just how embedded in modern government, in peace and in war have been strategies that lie outside criminalisation or that have their rationale in a perceived failure or inadequacy of criminalisation (for example, with respect to sex offender controls). We suggest that such phenomena are best understood not against the single criterion of presumed universalism of rule of law and human rights standards (themselves historically based and culturally determined) but against a more contextual, pragmatic and historical understanding of the development of the modern state. Such an understanding will recognise the inter-dependence of the modern state's governmental tasks, its institutional arrangements and its political constraints. In articulating the historical and philosophical grounds for insisting on the continuum of norm and emergency against the 'abstract consistency' of the norm/exception dichotomy, Lazar (2009: 14) has shown another way to capture these realities of liberal government. 
As much as governments face dilemmas in scope and scale of response to terrorism, so too their critics risk confusion in privileging particular standards in human rights law and criminal law process as the thresholds which liberal governments should not cross. For many legal critics, the 'rule of law' itself, rather than justice or order or liberty or safety or security, is a fundamental value which must be protected at all costs (Bronitt and McSherry 2010). Such privileging of 'rule of law' standards has been questioned on the grounds that they are really a means to an end, rather than an end in itself (Lazar 2009).

Expressing an anxiety widely held by critics of post 9/11 counter-terrorism law, Zedner wondered in 2005 whether we can hope 'to insulate the criminal process itself from the risk that its values will in turn be diluted by the normalisation of measures developed in respect of terrorism (Zedner 2005: 508). We suggest that this way of putting it turns the history upside down. Rather than counter-terrorist measures having the potential to leach into the normal criminal process, we suggest, instead, that it makes as much sense, if not more, to consider that the counter-terrorist measures enact strategies that have long been pursued by the modern liberal state's vision of securing its citizens in the interests of order and security, very often at the cost of individual liberty. In this light the criminal law has long faced the risk that its protections would be diluted by some other measure of government in pursuit of security (Ericson 2007; McSherry 2005, 2006).

We have considered three domains in which its protections have been sidelined while liberal government carried on the work of security. Critical socio-legal scholarship has found it easier to think of the genealogy of the idea of dangerousness in relation to the familiar terrain of class conflict (the oft cited image of the 'dangerous classes') than the more challenging and even unsettling discourse of mental illness. This has been the case even with more historicallyinformed scholars. Hence Pratt's (1997) otherwise wide-ranging genealogy of dangerousness ignored the discourse of dangerousness that originated in lunacy legislation. Similarly Zedner (2005: 37-9) has found the historical trope of the dangerous classes springing more readily to mind than that of the dangerous lunatic. We suggest that it makes sense to remember and account for the significance of 'dangerous' as an attribute of both a class and an individual when we consider the genealogy of state strategies exercised in defence of security against contemporary terrorism.

The networks of terrorism, real and imagined, bear, of course, much weight in the imaginary of the liberal state that constructs legal and governmental regimes to combat threats to public security. But the wrong-thinking and unpredictable behaviour of the individual who wages war against diverse enemies in unpredictable ways also calls up the array of responses that have long characterised the liberal state's management of those who refuse to be governed or be governable within the regimes of everyday life. In Hadfield's day millenarianism was widely read as madness and so justifying preventive detention in a madhouse (Harrison 1979: 207230). This is not to conclude or even hazard an argument about the state of mind or health of 'terrorists': rather, it is to insist that, in combating security threats, the liberal state has long adopted means that sidestep, avoid or are indifferent to the operations and concerns of the criminal law. Such responses do not stand outside law for it was the 1800 statute that made these things possible, and it was the operations of courts and a no doubt limited jurisprudence of habeas corpus that was its aider and abettor. In the longer run, the hazards of lunacy incarceration were themselves made the object of governmental innovation, through statute and tribunal. Nevertheless, such changes have not eliminated the reality that a power of compulsory and preventive detention that sits quite outside the frameworks and protections of criminal law, a persisting derogation of rights that yet have their defensible purpose, exist in the heart of the liberal state.

The criminalisation of political violence, or of violence pursued for millenarian ends (for example, the establishment of a sharia state, or of a revolutionary socialism or irredentist 
nationalism), is not a straightforward choice faced by governments - as the terrible events of the Hunger Strikes made clear in the years when the Thatcher Government pursued that strategy so relentlessly. Non-criminalising control policies, such as internment, equally face enormous obstacles in producing desired effects and run the risk of a counter-productive response, even of reproducing a next generation of zealotry. In peace-time emergency as in war, internment has, nevertheless, been a common security measure in the work of liberal government. Derogation of rights has been readily conceded by legislatures and political executives and judiciary (though always contested by some within these groups). The politics of emergency in liberal states has also nurtured a constant search for limiting the impact and reach of the conditions of internment and, for the most part, brought them to an end once emergency passed.

Of the three strategies we have considered, that governing the 'habitual criminal' and its contemporary legacies (the control of the sex offender; the measures targeting anti-social behaviour or bikie gangs) bears the closest relation to the functions of the criminal law. Remembering the history of such measures dating, as they do, back to the middle decades of the nineteenth century reminds us of the continuity of strategies of liberal government in pursuit of domestic security. Attributes of character, status and a history of criminal offending have all been held to justify derogation of rights in the absence of criminal law's capacity to address public and political anxieties about threats posed by individuals and groups bearing those attributes.

We conclude that the historical experience of rights derogations across a range of governmental interventions in the examples we have discussed provides some empirical grounding for further exploring what makes counter-terrorism law consistent with, rather than a new departure from, the development of liberal government. Conceding that counter-terrorist law may be grounded less in a derogation of hard-won due process rights than in an extension of long-standing strategies of liberal government in the management of security and safety may assist us to better appreciate the importance of other institutions of accountability and oversight in constraining over-reach and abuse of powers. From that position we may also acknowledge better the continuing achievement of political and administrative initiatives, responses and adjustments in shaping both the legal and governmental frameworks and practices of security.

Correspondence: Mark Finnane, Griffith University, Mt Gravatt, Qld, 4122, Australia. Email: m.finnane@griffith.edu.au

1 Mark Finnane is an ARC Australian Professorial Fellow and Chief Investigator, ARC Centre of Excellence in Policing and Security, Griffith University.

2 Susan Donkin is a Lecturer at the School of Criminology and Criminal Justice at Griffith University and an Associate Investigator with the ARC Centre of Excellence in Policing and Security.

3 Control orders aim to protect the public from a terrorist act by imposing restrictions and obligations on an individual suspected of posing a threat, against whom insufficient evidence exists to arrest and prosecute for a specific offence.

4 See, for example, Ashworth (2009: 101) - for whom the list of 'exceptions'(Art 5 (1) (e) to Art 5 of the European Convention on Human Rights (pertaining to liberty and security of the person) includes coercive measures taken in relation to lawful detention of persons for prevention of spread of infectious disease, 'of persons of unsound mind, alcoholics, drug addicts or vagrants' - a list he suggests has a 'rather dated appearance', for the inclusion of the term 'vagrants'. Indeed we should note that persons of unsound mind, or lunatics, first appeared in English vagrancy acts! (1714 and 1744).

5 See, for example, DG Security (Simpson) to Attorney-General (Evatt), 6 Nov 1942, NAA A373 (A373/1), 3075 Attachment. See also Bonner (2007) for the exercise of these mechanisms in Britain; and Simpson (1992).

6 A conviction was not a pre-requisite. Indeed, there are observation of these laws being used in cases where there was insufficient evidence to prosecute/convict (Horwitz 1995).

$7 \mathrm{~S} \mathrm{3(a)} \mathrm{states} \mathrm{that} \mathrm{the} \mathrm{first} \mathrm{object} \mathrm{of} \mathrm{the} \mathrm{Act} \mathrm{is} \mathrm{'to} \mathrm{provide} \mathrm{for} \mathrm{the} \mathrm{continued} \mathrm{detention} \mathrm{in} \mathrm{custody} \mathrm{or} \mathrm{supervised}$ release of a particular class of prisoner to ensure adequate protection of the community'. 


\section{References}

Agamben G (1998) Homo Sacer: Sovereign Power and Bare Life. Stanford, Calif: Stanford University Press.

Ashworth A (2009) Criminal law, human rights and preventative justice. In McSherry B, Norrie A and Bronitt S (eds) Regulating Deviance: The Redirection of Criminalisation and the Futures of Criminal Law. Oñati International Series in Law and Society. Oxford and Portland OR: Hart Publishing: 87-108.

Ashworth A (2010) Sentencing and Criminal Justice, 5th edn. Cambridge: Cambridge University Press.

Bevege M (1993) Behind Barbed Wire: Internment in Australia During World War II. St. Lucia, Qld: University of Queensland Press, UQP studies in Australian history.

Bonner D (2007) Executive Measures, Terrorism and National Security: Have the Rules of the Game Changed? Aldershot, England: Ashgate.

Bowden B and Davis MT (eds) (2008) Terror: From Tyrannicide to Terrorism. St. Lucia, Qld: University of Queensland Press.

Bronitt S and McSherry B (2010) Principles of Criminal Law, 3rd edn. Rozelle, NSW: Thomson Reuters.

Bronitt S (2008) Balancing security and liberty: Critical perspectives on terrorism law reform. In Gani M and Mathew P (eds) Fresh Perspectives on the War on Terror. Canberra: ANU E Press. Available at http://epress.anu.edu.au/war_terror/pdf/ch05.pdf (accessed 10 January 2013).

Bronitt S and Stellios J (2006) Sedition, security and human rights: 'Unbalanced' law reform in the 'War on Terror'. Melbourne University Law Review 30(3): 923-960.

Brown M and Pratt J (eds) (2000) Dangerous Offenders: Punishment and Social Order. London: Routledge.

Cole SA (2000) From the Sexual Psychopath Statute to 'Megan's Law': Psychiatric knowledge in the diagnosis, treatment, and adjudication of sex criminals in New Jersey, 1949-1999. Journal of the History of Medicine and Allied Sciences 55(3): 292-314.

Coleborne C (2003) Passage to the asylum; The role of the police in committals of the insane in Victoria, Australia, 1848-1900. In Porter R and Wright D (eds) The Confinement of the Insane: International Perspectives, 1800-1965. Cambridge: Cambridge University Press.

Daunton-Fear MW (1967) Habitual criminals and the indeterminate sentence. Adelaide Law Review 3: 335.

De Goede M (2008) The politics of preemption and the war on terror in Europe. European Journal of International Relations 14(1): 161-185.

Dershowitz A (1974a) Origins of preventive confinement in Anglo-American law - part I: The English experience. University of Cincinnati Law Review 43: 1-60.

Dershowitz A (1974b) Origins of preventive confinement in Anglo-American law - part II: The American experience. University of Cincinnati Law Review 43: 781-846.

Donohue LK (2001) Counter-terrorist Law and Emergency Powers in the United Kingdom, 19222000. Dublin: Irish Academic Press.

Dyzenhaus D (2006) The Constitution of Law: Legality in a Time of Emergency. Cambridge, UK: Cambridge University Press.

Eigen JP (1995) Witnessing Insanity: Madness and Mad-Doctors in the English Court. New Haven: Yale University Press.

Ericson RV (2007) Crime in an Insecure World. Cambridge, UK: Polity Press.

Finnane M (1981) Insanity and the Insane in Post-famine Ireland. London: Croom Helm. 
Finnane M (1996) Law and the social uses of the asylum in nineteenth century Ireland. In Tomlinson D and Carrier J (eds) Asylum in the Community. London and New York: Routledge.

Finnane M (2007) J V Barry: A Life. Sydney: UNSW Press.

Finnane M (2009) Controlling the 'alien' in mid-twentieth century Australia: The origins and fate of a policing role. Policing and Society 19(4): 442-467.

Fischer G (1989) Enemy Aliens: Internment and the Homefront Experience in Australia. St. Lucia, Qld: University of Queensland Press.

Forrester A (2002) Preventive detention, public protection and mental health. The Journal of Forensic Psychiatry 13(2): 329-334.

Fox RW (1978) So Far Disordered in Mind: Insanity in California, 1870-1930. Berkeley: University of California Press.

Freedman EB (1987) 'Uncontrolled desires': The response to the sexual psychopath, 1920-1960. The Journal of American History 74(1): 83-106.

Gani M (2008) How does it end? Reflections on completed prosecutions under Australia's antiterrorism legislation. In Gani M and Mathew P (eds) Fresh Perspectives on the War on Terror. Canberra: ANU E Press.

Garton S (1987) Policing the dangerous lunatic: Lunacy incarceration in NSW, 1870-1914. In Finnane M (ed) Policing in Australia: Historical Perspectives. Kensington, NSW: New South Wales University Press

Harrison JFC (1979) The Second Coming: Popular Millenarianism, 1780-1850. New Brunswick, N.J: Rutgers University Press.

Horwitz A (1995) Sexual psychopath legislation: Is there anywhere to go but backwards? University of Pittsburgh Law Review 35: 35-78.

International Commission of Jurists (2009) Assessing Damage, Urging Action: Report of the Eminent Jurists Panel on Terrorism, Counter-terrorism and Human Rights. Geneva: International Commission of Jurists.

Koessler M (1942) Enemy alien internment: With special reference to Great Britain and France. Political Science Quarterly 57(1): 98-127.

Lamidey NW (1974) Aliens Control in Australia, 1939-46. Sydney: N Lamidey.

Lazar NC (2009) States of Emergency in Liberal Democracies, 1st edn. Cambridge: Cambridge University Press.

Loader I and Walker N (2007) Civilizing Security. Cambridge: Cambridge University Press.

Lustgarten L and Leigh I (1994) In from the Cold: National Security and Parliamentary Democracy. Oxford: Clarendon Press.

Lynch A (2007) Achieving security, respecting rights and maintaining the rule of law. In Lynch A, Williams G and MacDonald E (eds) Law and Liberty in the War on Terror. Leichhardt, NSW: Federation Press.

McCandless P (1996) Moonlight, Magnolias \& Madness: Insanity in South Carolina from the Colonial Period to the Progressive Era. Chapel Hill: UNC Press Books.

McCulloch J and Pickering S (2009) Pre-crime and counter-terrorism: Imagining future crime in the 'War on Terror'. British Journal of Criminology 49: 628-645.

McSherry B (2005) Indefinite and preventive detention legislation: From caution to an open door. Criminal Law Journal 29(2): 94-110.

McSherry B (2006) Sex, drugs and 'evil' souls: The growing reliance on preventive detention regimes. Monash University Law Review 32(2): 237-274.

Michaelsen C (2005) International human rights on trial - the United Kingdom's and Australia's legal response to 9/11. Sydney Law Review 25(3): 275-303. 
Moran R (1985a) The modern foundation for the insanity defense: The cases of James Hadfield (1800) and Daniel McNaughtan (1843). Annals of the American Academy of Political and Social Science 477 (January 1): 31-42.

Moran R (1985b) The origin of insanity as a special verdict: The trial for treason of James Hadfield (1800). Law \& Society Review 19(3) (January 1): 487-519.

Morris N (1951) The Habitual Criminal. London: Longmans.

Neumann K (2006) In the Interest of National Security: Civilian Internment in Australia during World War II / Klaus Neumann. Canberra: National Archives of Australia.

Ngai MM (2004) Impossible Subjects: Illegal Aliens and the Making of Modern America. Princeton, NJ: Princeton University Press, Politics and society in twentieth-century America.

Pratt J (1997) Governing the Dangerous. Sydney: The Federation Press.

Prior PM (2003) Dangerous lunacy: The misuse of mental health law in nineteenth-century Ireland. Journal of Forensic Psychiatry \& Psychology 14(3): 525-541.

Radzinowicz L and Hood R (1990) The Emergence of Penal Policy in Victorian and Edwardian England. Oxford: Clarendon Press.

Richardson L (2006) What Terrorists Want: Understanding the Enemy, Containing the Threat, 1st edn. New York: Random House.

Saunders D (2010) Anti-security personae: From David Dyznehaus's Human Rights Lawyer to Giorgio Agamben's Illuminato. In Yeatman A and Żółkoś M (eds) State, Security, and Subject Formation. New York: Continuum.

Sharpe RJ (1989) The Law of Habeas Corpus, 2nd edn. Oxford, England: Clarendon Press.

Simon J (1998) Managing the monstrous: Sex offenders and the new penology. Psychology, Public Policy, and Law 4(1-2): 452-467.

Simpson AWB (1992) In the Highest Degree Odious: Detention Without Trial In Wartime Britain. Oxford: Clarendon Press.

Smith R (1981) Trial by Medicine: Insanity and Responsibility in Victorian Trials. Edinburgh: Edinburgh University Press.

Sutherland EH (1950) The diffusion of sexual psychopath laws. The American Journal of Sociology 56(2): 142-148.

Townshend C (1986) Britain's Civil Wars: Counterinsurgency in the Twentieth Century, 1st edn. London: Faber \& Faber, July.

Townshend C (2009) Martial law: Legal and administrative problems of civil emergency in Britain and the Empire, 1800-1940. The Historical Journal 25(01) (February): 167-195.

Walker N (1968) Crime and Insanity in England. Edinburgh: University Press.

Williams C (2011) Labeling and tracking the criminal in mid-nineteenth century England and Wales: The relationship between governmental structures and creating official numbers. In Saetnan AR, Lomell HM and Hammer S (eds) The Mutual Construction of Statistics and Society. New York and Abingdon: Taylor \& Francis: 157-171.

Wormith JS and Ruhl M (1986) Preventive detention in Canada. Journal of Interpersonal Violence 1(4): $399-430$.

Zedner L (2005) Securing liberty in the face of terror: Reflections from criminal justice. Journal of Law and Society 32(4) (December): 507-533.

Zedner L (2007) Preventive justice or pre-punishment? The case of control orders. Current Legal Problems 60(1): 174-203.

Zedner L (2009) Fixing the future? The pre-emptive turn in criminal justice. In McSherry B, Norrie A and Bronitt S (eds) Regulating Deviance: The Redirection of Criminalisation and the Futures of Criminal Law. Oxford: Hart. 